\title{
ST2 DEFICIENCY AMELIORATES HIGH FAT DIET-INDUCED LIVER STEATOSIS IN BALB/C MICE
}

\author{
Nemanja Jovicic ${ }^{1,2,}$, Ilija Jeftic ${ }^{1,3^{*}}$, Marina Miletic Kovacevic ${ }^{2}$, Irena Tanaskovic ${ }^{2}$, Nebojsa Arsenijevic ${ }^{1}$, Miodrag L. Lukic ${ }^{1}$, Nada Pejnovic ${ }^{1,3^{*}}$ \\ ${ }^{1}$ Center for Molecular Medicine; \\ ${ }^{2}$ Institute of Histology; \\ ${ }^{3}$ Institute of Pathophysiology, Faculty of Medical Sciences, University of Kragujevac, Kragujevac, Serbia

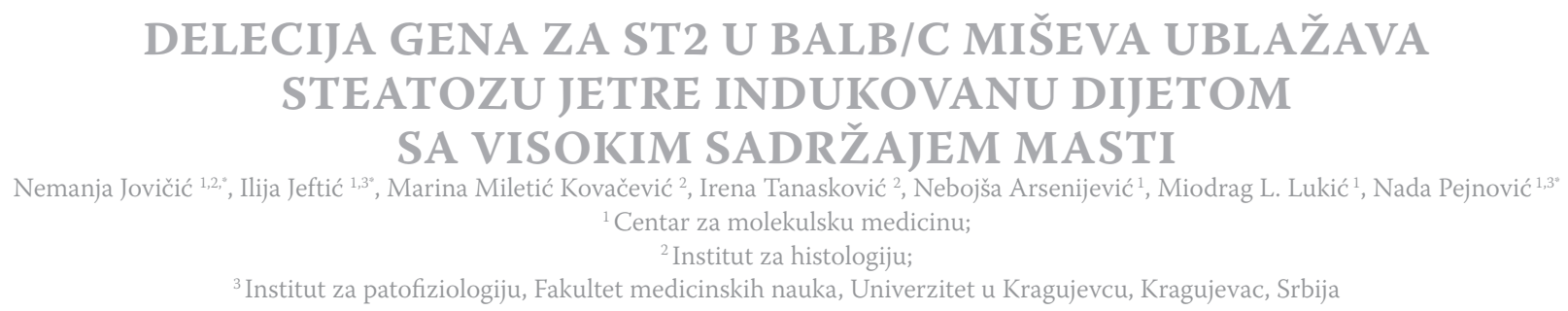

Received / Primljen: 12. 02. 2015.

*The authors NJ and IJ contributed equally to this study.

Accepted / Prihvaćen: 24. 02. 2015.

\begin{abstract}
Non-alcoholic fatty liver disease (NAFLD) is strongly associated with obesity, but the molecular mechanisms of liver steatosis and its progression to non-alcoholic steatohepatitis and fibrosis are incompletely understood. Immune reactivity plays an important role in the pathogenesis of NAFLD. The IL-33/ST2 axis has a protective role in adiposity and atherosclerosis, but its role in obesity-associated metabolic disorders requires further clarification. To investigate the unresolved role of IL-33/ST2 signalling in NAFLD, we used ST2-deficient (ST2-) and wild type (WT) BALB/c mice maintained on a high-fat diet (HFD) for 24 weeks. HFDfed ST2- mice exhibited increased weight gain, visceral adipose tissue weight and triglyceridaemia and decreased liver weight compared with diet-matched WT mice. Compared with WT mice on an HFD, ST2 deletion significantly reduced hepatic steatosis, liver inflammation and fibrosis and downregulated the expression of genes related to lipid metabolism in the liver. The frequency of innate immune cells in the liver, including $C D 68^{+}$macrophages and $C D 11 c^{+}$ dendritic cells, was lower in HFD-fed ST2- mice, accompanied by lower TNFa serum levels compared with dietmatched WT mice. Less collagen deposition in the livers of ST2 $\%$ mice on an HFD was associated with lower numbers of profibrotic CD11b+Ly6clow monocytes and CD $4^{+} I L-17^{+} T$ cells in the liver, lower hepatic gene expression of procollagen, IL-33 and IL-13, and lower serum levels of IL-33 and IL-13 compared with diet-matched WT mice.

Our findings suggest that the IL-33/ST2 axis may have a complex role in obesity-associated metabolic disorders. Although it is protective in HFD-induced adiposity, the IL-33/ ST2 pathway promotes hepatic steatosis, inflammation and fibrosis.
\end{abstract}

Key words: Obesity, steatosis, non-alcoholic steatohepatitis, liver fibrosis, immune cells

\section{SAŽETAK}

Nealkoholna masna bolest jetre je najčešće udružena sa gojaznošću, ali su molekularni mehanizmi razvoja steatoze i progresije u stetaohepatitis i fibrozu jetre nedovoljno razjašnjeni. Imunski mehanizmi imaju važnu ulogu u razvoju nealkoholne masne bolesti jetre. IL-33/ST2 signalni put ima zaštitnu ulogu u gojaznosti i aterosklerozi, ali je njegova uloga u razvoju metaboličkih poremećaja udruženih sa gojaznošću nedovoljno ispitana.

U ovom istraživanju ispitivali smo ulogu IL-33/ST2 signalnog puta u nealkoholnoj masnoj bolesti jetre na mišjem modelu gojaznosti indukovane primenom dijete sa visokim sadržajem masti u trajanju od 24 nedelje na ST2 deficijentnim $\left(S T 2^{-\digamma}\right)$ i miševima divljeg soja BALB/c.

ST2- miševi na dijeti sa visokim sadržajem masti su imali veći prirast telesne težine, veću težinu visceralnog masnog tkiva $i$ više serumske nivoe triglicerida, dok je težina jetre bila manja u pređenju sa miševima divljeg soja na istoj dijeti. Nadalje, delecija ST2-- gena je značajno smanjila steatozu jetre, inflamaciju i fibrozu jetre što je bilo praćeno sniženom ekspresijom gena uključenih u metabolizam lipida u jetri. Zastupljenost ćelija prirodne imunosti u jetri, $C D 68^{+}$makrofaga i $C D 11 c^{+}$dendritskih ćelija i serumski nivo TNFa su bili niži kod ST2-- miševa. Manje izražena fibroza jetre u ST2- miševa je bila povezana sa sniženom zastupljenošću profibrotskih $C D 11 b^{+} L y 6 c^{\text {low }}$ monocita i CD4+ IL-17+ T limfocita u jetri, sniženom ekspresijom gena za prokolagen, IL-33 i IL-13 i sniženim serumskim nivoima IL-33 i IL-13 u poredjenju sa miševima divljeg soja.

Dobijeni rezultati ukazuju na kompleksnu ulogu IL33/ST2 signalnog puta u metaboličkim poremećajima udruženim sa gojaznošću. Iako protektivan za razvoj gojaznosti, IL-33/ST2 signalni put pospešuje steatozu, inflamaciju i fibrozu jetre.

Ključne reči: gojaznost, steatoza, nealkoholni steatohepatitis, fibroza jetre, imunske ćelije 


\section{ABBREVIATIONS}

ABCA - ATP-binding cassette transporter BSA - bovine serum albumin CD - cluster of differentiation CDNA - complementary DNA FCS - foetal calf serum FFAs - free fatty acids Gal-3 - galectin 3 HFD - high fat diet IFN $\gamma$ - interferon- $\gamma$ IL - Interleukin

LXR $\boldsymbol{\alpha}$ - Liver X receptor alpha
NAFLD - non-alcoholic fatty liver disease

NASH - non-alcoholic steatohepatitis

PBS - phosphate-buffered saline

PPAR - peroxisome proliferator-activated receptor gamma qRT-PCR - quantitative real-time polymerase chain reaction

RNA - Ribonucleic acid

TNF $\alpha$ - tumour necrosis factor alpha

VAT - visceral adipose tissue

VLDL - very low density lipoprotein

WT - wild type

o-SMA - alpha smooth muscle actin

\section{INTRODUCTION}

Non-alcoholic fatty liver disease (NAFLD) is the most common liver disease in developed countries and comprises a wide spectrum of liver pathologies, from benign liver steatosis to non-alcoholic steatohepatitis (NASH), eventually causing liver cirrhosis that may lead to hepatocellular carcinoma (1). Approximately one third of the individuals with simple steatosis develop NASH, and among them, up to $20 \%$ will progress to liver cirrhosis over the period of years (2).

NAFLD is considered as a hepatic manifestation of metabolic syndrome, which is a cluster of interrelated metabolic disorders, including obesity, hypertension and atherosclerosis, insulin resistance and diabetes, and dyslipidemia and fatty liver. The central features of metabolic syndrome are related to lipotoxicity, glucotoxicity and chronic low-grade inflammation leading to insulin resistance $(3,4)$, for which immune mechanisms and complex cytokine network coordinate the inflammatory responses and metabolic disturbances $(3,5)$. Genetic and environmental factors play a role in the development of obesity $(6,7)$, but the cellular and molecular mechanisms involved in obesity-associated metabolic disorders are incompletely understood.

The hallmark of NAFLD is hepatocyte triglyceride accumulation. Hepatic steatosis represents excessive fat accumulation in hepatocytes and occurs as a result of multiple metabolic pathways, including increased fat delivery, increased fat synthesis, reduced fat oxidation, and/ or reduced fat export in the form of VLDL (8). Increased circulating fatty acids (FFAs) and de novo lipogenesis from glucose are important determinants of hepatic steatosis. Adipose tissue dysfunction in obesity is thought to increase plasma FFAs, which are the major lipid providers in hepatic steatosis, and ectopic lipid accumulation in liver and muscle tissues, leading to insulin resistance. The mechanisms that lead to excessive plasma FFAs include increased lipolysis in adipose tissue, increased dietary fatty acids and newly synthesized fatty acids in the liver that are esterified into triglycerides and either stored in hepatocyte lipid droplets or secreted as plasma VLDLs (9).

The molecular mechanisms involved in the progression of benign liver steatosis to liver inflammation and fibrosis in NA-
FLD are incompletely understood. Hepatic lipid accumulation may promote the inflammatory response characterized by activated resident tissue macrophages (Kupffer cells), the increased infiltration of myeloid and lymphoid cells within the liver and the subsequent release of pro-inflammatory cytokines, including TNF- $\alpha$, IL- 6 and IL- $1 \beta$, all of which enhance the progression of NASH to fibrosis. Moreover, the most recent study demonstrated that development of hepatic steatosis requires IL-1 signalling, which promotes hepatic lipogenesis (10). Other members of the IL-1 superfamily, including the IL- 1 receptor antagonist, IL-18 and IL-33, together with IL-1 have been implicated in various pathological conditions, but their roles in obesity-associated metabolic disorders are unclear.

IL-33 is a member of the IL-1 cytokine family, a multifunctional cytokine involved in the pathogenesis of various inflammatory and autoimmune diseases (11). IL-33 is a pleiotropic cytokine that binds to its plasma membrane receptor complex comprising ST2 and the IL-1R accessory protein (11) and generally promotes Th2-type immune responses. IL33 appears to exert protective metabolic effects in obesity and atherosclerosis (12). IL-33 promotes liver fibrosis through the activation and expansion of liver-resident innate lymphoid cells, which produce profibrotic IL-13 (13). In the fibrotic liver, IL-33 is present in activated hepatic stellate cells, which are key cellular mediators of liver fibrosis (14).

The role of the IL-33/ST2 axis in obesity-associated metabolic disorders requires further clarification. We aimed to investigate the role of IL-33/ST2 signalling in the development of hepatic steatosis, inflammation and fibrosis in a model of high fat diet (HFD)-induced obesity using ST2-deficient $\left(\mathrm{ST}^{-/}\right)$mice on the BALB/c background.

\section{MATERIALS AND METHODS}

\section{Experimental mice and study design}

Eight-week-old, male mice were used in the experiments. ST2-deficient mice (ST2 ${ }^{-/-}$mice) on the BALB/c background were generated by targeted disruption of the 
mouse ST2 gene (15). ST2 $2^{-/}$mice were kindly provided by Dr McKenzie (University of Cambridge, UK). ST2-deficient (ST2-/-) and wild-type (WT) BALB/c mice were accommodated in our animal facilities under standard laboratory conditions in a temperature-controlled environment with a 12-h light/dark cycle. Mice received water and standard chow (10\% calories from fat, Mucedola, Milano, Italy) or a high fat diet (60\% calories from fat, Mucedola, Italy) ad libitum. Animals were sacrificed after 24 weeks of feeding, and blood samples and liver and visceral adipose tissues were collected for further analyses. All animal procedures were approved by the Ethical committee of the Faculty of Medical Sciences, University of Kragujevac.

\section{Metabolic parameters}

Body weights and fasting blood glucose levels were measured periodically, every 4 weeks. Before the measurements, mice were fasted for $4 \mathrm{~h}$, and glucose levels $(\mathrm{mmol} / \mathrm{L})$ were determined using the Accu-Chek Performa glucometer (Roche Diagnostics, Mannheim, Germany). Serum concentrations of total cholesterol, triglycerides, AST and ALT were measured using the Olympus AU600 Chemistry Immuno Analyzer (Olympus, Tokyo, Japan). Fasting insulin levels in sera were measured using the Mouse Insulin ELISA Kit (Alpco, Salem, NH, USA).

\section{Liver histological analysis}

Livers were excised, fixed in $10 \%$ buffered formalin and embedded in paraffin. Tissue sections, 5- $\mu$ m-thick, were stained with haematoxylin and eosin and picrosirius red as previously described (16). The quantification of redstained collagen in liver sections stained with picrosirius red was performed on 10 fields of a section at $10 \mathrm{X}$ magnification, as previously described (17).

We performed Oil Red O staining on 5 - $\mu$ m-thick liver tissue cryosections. Tissue sections were fixed in paraformaldehyde (10\%), rinsed with $60 \%$ isopropanol and stained with freshly prepared a working solution of Oil Red $\mathrm{O}$ for 10 minutes. After rinsing with $60 \%$ isopropanol, sections were counterstained with Mayer's haematoxylin and mounted using water-based mounting medium. The quantification of red-stained lipids in mouse liver sections stained with Oil Red $\mathrm{O}$ was performed on 10 fields of a section at $100 \mathrm{X}$ magnification by digital image analyses, as previously described (18).

The quantification of liver tissue inflammatory cell infiltration was performed in blinded fashion by two independent observers. Analysis was performed on 10 fields of a section at 10X magnification. Inflammatory cell infiltration was graded as follows: $0=$ no foci; $1=<2$ foci/field; $2=2-4$ foci per field; and $3=>4$ foci per field. Then, a mean score was calculated (19). Histological analysis was performed on tissue sections using light microscope (BX51; Olympus) equipped with a digital camera.

\section{Immunohistochemistry}

For immunohistochemical staining, we used paraffinembedded liver tissue sections $(5-\mu$ m-thick). After performing heat-mediated antigen retrieval in citrate buffer $(\mathrm{pH}=6.0)$, deparaffinized tissue sections were incubated with primary mouse anti- $\alpha$-SMA antibody (ab7817, Abcam, Cambridge, UK) or mouse anti-CD68 antibody (ab49777, Abcam). Staining was visualized using the Mouse-specific HRP/DAB Detection IHC Kit (ab64259, Abcam), and sections were counterstained with Mayer's haematoxylin. Sections were photomicrographed with a digital camera mounted on a light microscope (Olympus BX51, Japan), digitized and analysed. Analysis was performed on 10 fields of a section at 40X magnification. The results are presented as the mean count of positively stained cells per field.

\section{Isolation of liver mononuclear cells}

The mice were euthanized, and their livers were removed, thoroughly dissected and passed through a 100$\mu \mathrm{m}$ nylon cell strainer (BD Biosciences); isolated cells were then suspended in complete RPMI-1640 medium containing $10 \%$ foetal calf serum (FCS). Cell suspensions were centrifuged at $507 \mathrm{rpm}$ for 1 minute, and the supernatants enriched for mononuclear cells were collected and centrifuged at $1500 \mathrm{rpm}$ for 10 minutes, as previously described (20). Cell pellets were then resuspended in complete RPMI-1640 medium.

\section{Flow cytometry}

Liver mononuclear cells were stained with combinations of either fluorochrome-labelled primary Abs or isotype controls for $30 \mathrm{~min}$ at $4^{\circ} \mathrm{C}$. For intracellular staining, cells were activated with PMA/ionomycin and processed as previously described (21). Cells were labelled with the following fluorochrome-conjugated monoclonal antibodies: anti-mouse CD3, CD11b, CD45, CD4, (BD Biosciences), F4/80, CD11c (BioLegend, San Diego, CA), and Ly-6C (Life Technologies, Carlsbad, CA). The cells were analysed using a FACSCalibur flow cytometer (BD Biosciences) and FlowJo software (Tree Star).

\section{Expression of genes related to lipid metabolism and fibrosis in the liver}

RNA was extracted from frozen mouse liver tissue using TRIzol (Invitrogen, Carlsbad, CA) according to the manufacturer's instructions. Total RNA $(2 \mu \mathrm{g})$ was reversetranscribed to cDNA using the High Capacity cDNA Reverse Transcription Kit (Applied Biosystems, Foster City, California, USA). qRT-PCR was performed using Power SYBR MasterMix (Applied Biosystems) and miRNA-specific primers for procollagen, $\alpha$ SMA, IL-33, CD36, IL-13, TGF- $\beta$, Abca-1, LXR $\alpha$, and PPAR $\gamma$ as well as for $\beta$-actin, as 
Table 1: Primers used for qRT-PCR analysis

\begin{tabular}{|c|c|c|}
\hline & Sense $\left(5^{\prime}\right.$ to $\left.3^{\prime}\right)$ & Antisense (5' to $\left.3^{\prime}\right)$ \\
\hline Procollagen & GCTCCTCTTAGGGGCCACT & CCACGTCTCACCATTGGGG \\
\hline$\alpha$-SMA & ACTGGGACGACATGGAAAAG & CATCTCCAGAGTCCAGCACA \\
\hline IL-33 & TCCTTGCTTGGCAGTATCCA & TGCTCAATGTGTCAACAGACG \\
\hline IL-13 & CCTGGCTCTTGCTTGCCTT & GGTCTTGTGTGATGTTGCTCA \\
\hline TGF- $\beta$ & ATACAGGGCTTTCGATTCAGC & GTCCAGGCTCCAAATATAGG \\
\hline mLXR- $\alpha$ & ATCGCCTTGCTGAAGACCTCTG & GATGGGGTTGATGAACTCCACC \\
\hline PPAR-Y & CCCAATGGTTGCTGATTACAAA & GAGGGTGTTAGAAGGTTCTTCATGA \\
\hline Abca-1 & CGCAGTGACCAGAAAACAATGTG & TATCAATGAGGCAAGGGTGTGG \\
\hline CD36 & TCCAGCCAATGCCTTTGC & TGGAGATTACTTTTTCAGTGCAGAA \\
\hline
\end{tabular}

a housekeeping gene (Table 1 ). $\mathrm{qPCR}$ reactions were initiated with a 10 -minute incubation time at $95^{\circ} \mathrm{C}$ followed by 40 cycles of $95^{\circ} \mathrm{C}$ for 15 seconds and $60^{\circ} \mathrm{C}$ for 60 seconds in a Mastercycler ${ }^{\circledR}$ ep realplex (Eppendorf, Hamburg, Germany). The fold change of miRNA gene expression was calculated by the equation $2^{-\Delta \Delta C t}$, described by Livak and Schmittgen (22), where $\mathrm{Ct}$ is the cycle threshold. $\Delta \mathrm{Ct}$ was calculated by subtracting the $\mathrm{Ct}$ values of the endogenous control from the $\mathrm{Ct}$ values of the miRNA of interest. $\Delta \Delta \mathrm{Ct}$ was then calculated by subtracting $\Delta \mathrm{Ct}$ of the control from $\Delta \mathrm{Ct}$ of the calibrator.

\section{Cytokine measurements}

Cytokine levels in sera were measured using mouse Duoset ELISA kits for IL-6, IL-10, IL-13, IL-33, TGF- $\beta$, IFN- $\gamma$ and TNF- $\alpha$ (R\&D Systems, Minneapolis, MN, USA) according to the manufacturer's instructions.

\section{Statistical analysis}

Statistical analysis was performed using SPSS 22.0. Data are presented as the means \pm SEM. Statistical significance was assessed by the Mann-Whitney U test, and, if appropriate, independent sample Student's t test. Statistical significance was assumed at $\mathrm{p}<0.05$.

\section{RESULTS}

Metabolic analysis in WT and $\mathrm{ST}^{-/-} \mathrm{BALB} / \mathrm{c}$ mice exposed to an HFD

At the beginning of the experiment, $\mathrm{WT}$ and $\mathrm{ST}^{-1}$ BALB/c mice had similar body weights. After 24 weeks of feeding with either chow or an HFD, no differences in body weights were observed between WT and ST2-- mice. However, the weight gain and the weight gain expressed as a percentage of the initial body weight were significantly higher in ST2 ${ }^{-1-}$ mice on an HFD compared with dietmatched WT mice (Fig. 1A).
The visceral adipose tissue (VAT) weight and the VAT weight expressed as a percentage of total body weight were significantly higher in HFD-fed mice of both genotypes compared with chow-fed mice. The visceral adipose tissue weight was significantly higher in HFD-fed ST2 $2^{-1-}$ mice compared with HFD-fed WT mice (Fig. 1A). The liver weight and the liver weight expressed as a percentage of the total body weight were significantly lower in ST2-- mice on an HFD compared with HFD-fed WT mice (Fig. 1A). Fasting blood glucose levels and the HbA1c percentage did not differ in HFD-fed mice of both genotypes, whereas fasting serum insulin levels were significantly lower in $\mathrm{ST}^{-/-}$mice compared with WT mice (Fig. 1B).

Serum triglycerides were significantly higher in HFDfed ST2 ${ }^{--}$vs. WT mice as well as compared with chow-fed $\mathrm{ST}^{-1-}$ mice. An HFD significantly increased total cholesterol serum levels in both genotypes, with no significant differences observed between ST2 ${ }^{--}$and WT mice (Fig. 1C). ALT activity was significantly increased in HFD-fed WT and ST2 $2^{-1}$ mice compared with chow fed mice, with no differences found between the genotypes (Fig. 1D). AST levels did not differ between chow- or HFD-fed ST2 ${ }^{-/}$and WT mice.

\section{Liver steatosis, inflammation and fibrosis in WT} and $\mathrm{ST}_{2}^{-/-} \mathrm{BALB} / \mathrm{c}$ mice

Semiquantitative analysis of lipid deposition in liver tissue sections stained with Oil Red $\mathrm{O}$ demonstrated that HFD increased liver steatosis in WT and ST2 $2^{-1}$ mice compared with chow-fed animals. However, liver steatosis was significantly lower in ST2 $\%$ mice on an HFD compared with diet-matched WT mice (Fig. 2A). Liver inflammation, as evaluated by the inflammatory cell infiltrate score, was significantly lower in ST2 ${ }^{-/}$mice on an HFD compared with diet-matched WT mice (Fig. 2B). The degree of liver fibrosis, quantified by staining collagen with picrosirius red, was significantly higher in both genotypes of mice fed an HFD compared with chow-fed mice. Notably, the degree of collagen deposition was significantly lower in HFD-fed $\mathrm{ST}_{2}{ }^{-/}$mice compared with HFD-fed WT mice (Fig. 2C). 

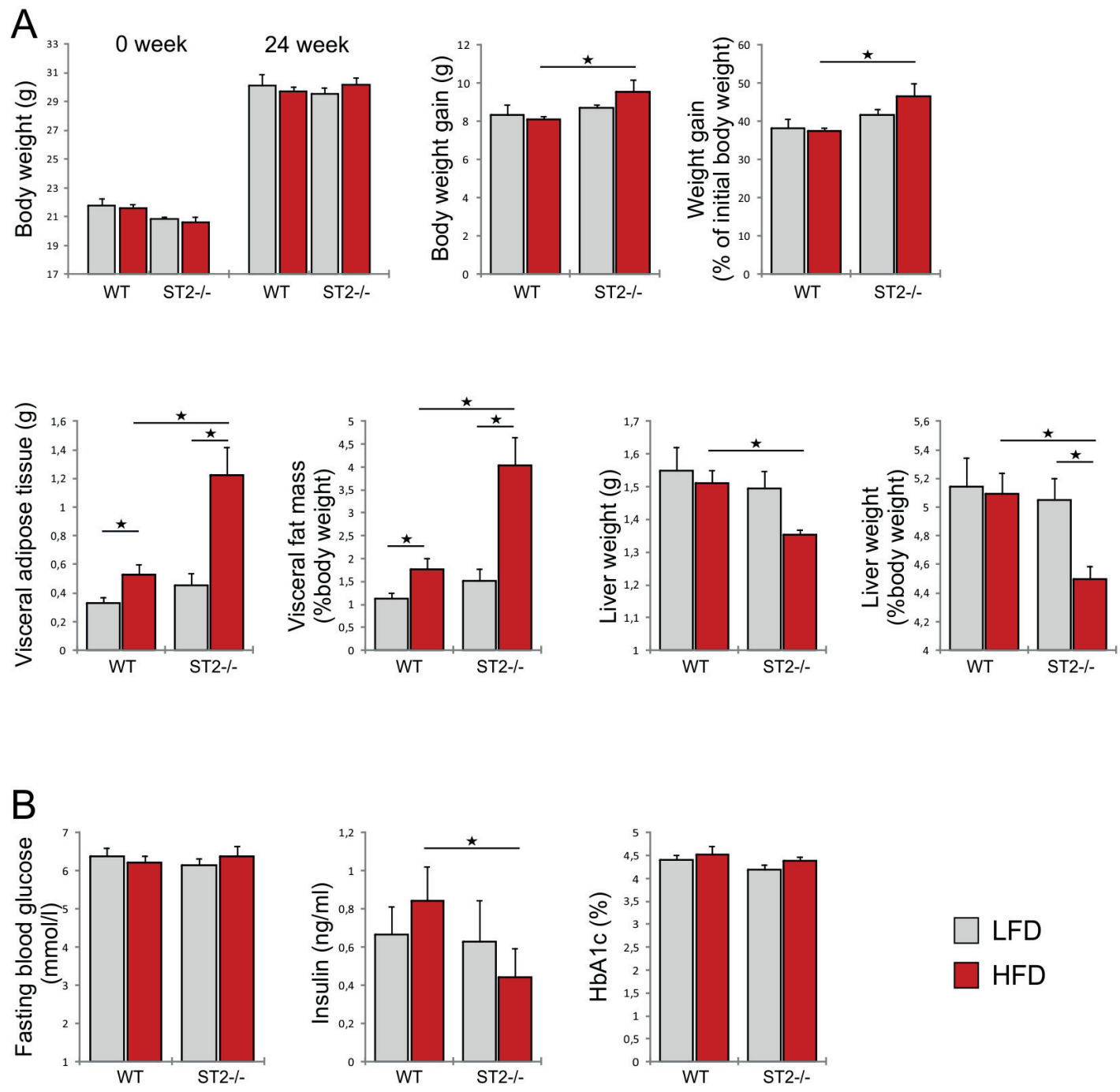

\section{C}
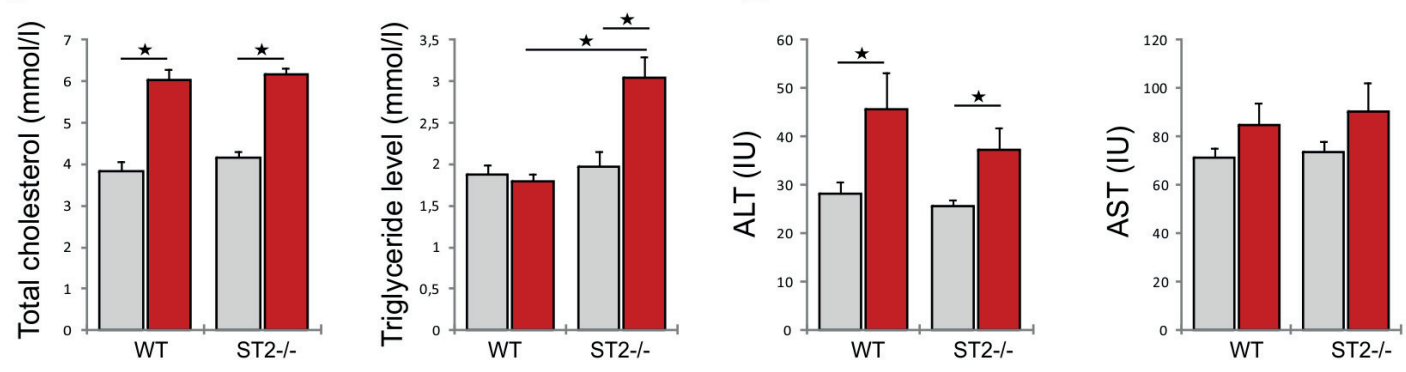

Figure 1. Metabolic parameters

A. Body weight at the beginning of the experiment and after 24 weeks. Body weight gain as well as weight gain expressed as a percentage of the initial body weight were significantly higher in ST2 ${ }^{-/}$mice on a high-fat diet compared with diet-matched WT mice. The visceral adipose tissue weight and its weight expressed as a percentage of the total body weight were significantly higher in high-fat diet-fed vs. chow-fed groups of mice of both genotypes. The visceral adipose tissue weight was significantly higher in HFD-fed ST2 ${ }^{--}$mice compared with HFD-fed WT mice. The liver weight and the liver weight expressed as a percentage of the total body weight were significantly lower in ST2 ${ }^{-1-}$ mice fed an HFD compared with diet-matched WT mice.

B. There was no difference in fasting blood glucose levels between groups. Fasting serum insulin levels was significantly lower in ST2 ${ }^{-/}$mice compared with WT mice, both fed an HFD.

C. Total cholesterol levels in the sera were significantly higher in the HFD-fed groups compared with the respective chow diet-fed groups. ST2 ${ }^{--}$mice fed an HFD had significantly higher levels of serum triglycerides compared with ST2 $2^{--}$as well as WT mice fed a chow diet.

D. ALT activity was significantly increased in WT and ST2 $2^{-/}$mice fed an HFD compared with the respective chow-fed groups. There were no differences in AST activity between groups. 
口医
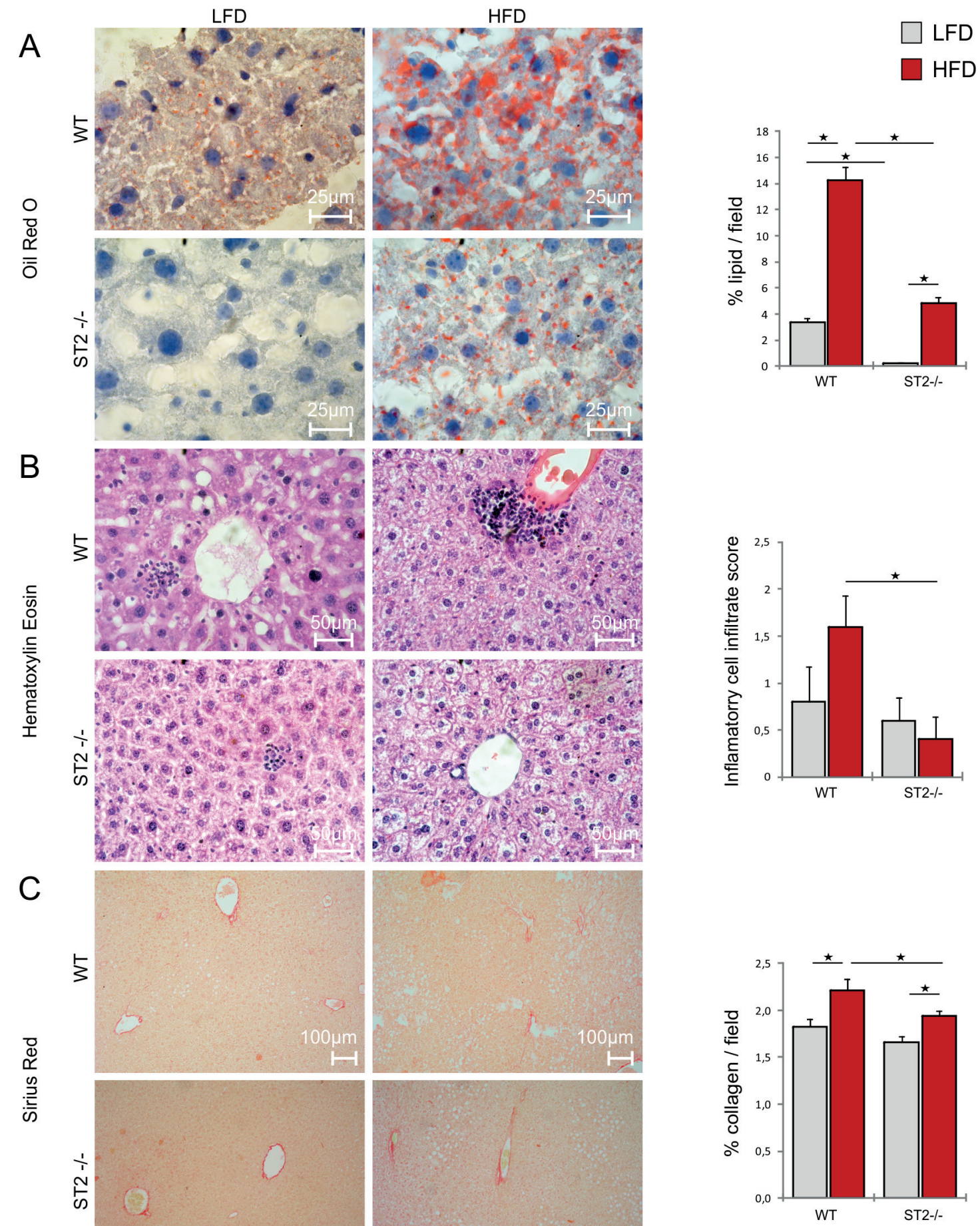

Figure 2. Liver steatosis, inflammation and fibrosis

A. Significantly higher liver steatosis was observed in WT mice fed an HFD compared with WT mice fed chow. Significantly higher liver steatosis was observed in ST2 ${ }^{-/-}$mice fed an HFD compared with ST2 $2^{--}$mice fed chow. Liver steatosis was significantly lower in ST2 $2^{-/-}$mice than in WT mice, both fed an HFD.

B. Liver inflammation, as evaluated by the inflammatory cell infiltrate score, was significantly lower in HFD-fed ST2 ${ }^{-/-}$mice compared with HFD-fed WT mice.

C. The degree of liver fibrosis was significantly higher in mice fed an HFD compared with mice fed a chow diet in both genotypes. The extent of liver fibrosis was significantly lower in ST2 $2^{-\leftarrow}$ mice fed an HFD compared with diet-matched WT mice. 

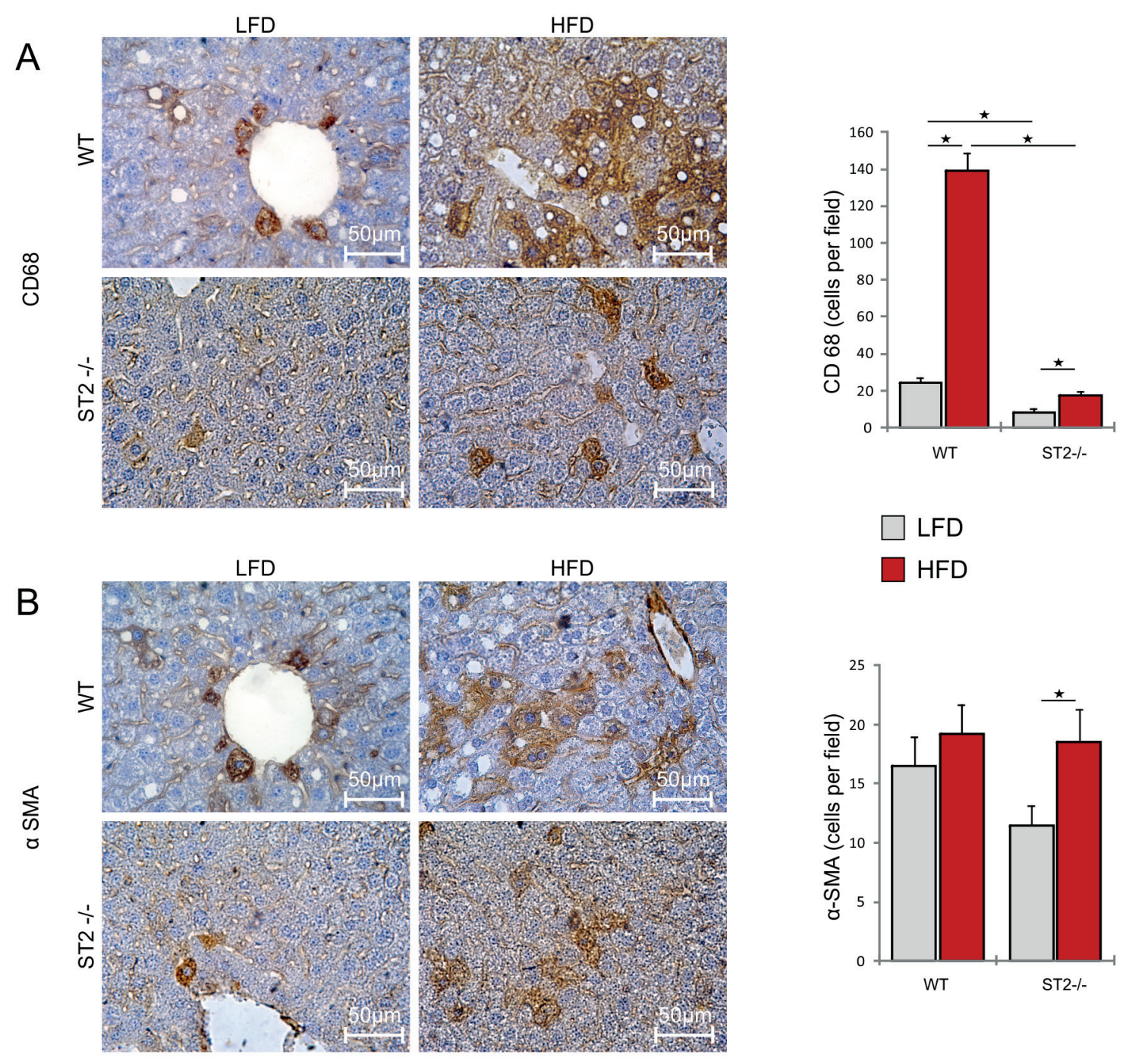

$\square$ LFD

$\square \mathrm{HFD}$

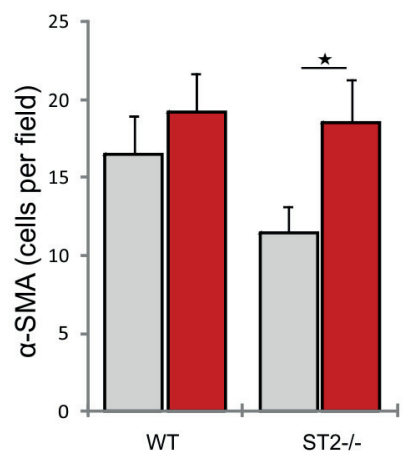

Figure 3. Immunohistochemical staining in liver

A. Number of $\alpha$ SMA positive cells was significantly lower in ST2-/- mice on chow diet compared to ST2-/- mice on HFD, with no differences between the genotypes of mice

B. The number of CD68+ macrophages was significantly lower in ST2-/- mice on chow diet compared to ST2-/- mice on HFD as well as WT mice on chow. ST2-/- mice on HFD had significantly lower number of CD68+ macrophages compared to WT mice on HFD. Wild type mice on chow had significantly lower number of CD68+ macrophages compared to WT mice on HFD.

HFD significantly increased the number of $\mathrm{CD} 68^{+}$macrophages in livers in WT and ST2 ${ }^{-1}$ mice. However, the number of $\mathrm{CD} 68^{+}$macrophages was significantly lower in chow- or HFD-fed ST2 ${ }^{-1}$ mice compared with diet-matched WT mice (Fig 3A). HFD feeding significantly increased the number of $\alpha$ SMA-positive myofibroblasts in the livers of $\mathrm{ST}^{-/-}$mice only; there was no difference in the number of aSMA-positive cells between the two genotypes of mice fed chow or an HFD (Fig. 3B).

Immune cell composition in the livers of $\mathrm{WT}$ and $\mathrm{ST} 2^{--} \mathrm{BALB} / \mathrm{c}$ mice

We analysed several populations of innate immune cell and lymphocyte subpopulations. HFD feeding increased the percentage of $\mathrm{F} 4 / 80^{+}$macrophages in the livers of WT mice; in contrast, no significant differences in the proportion of these cells were found between WT and ST2 $2^{-/}$mice on an HFD. The percentage of CD11 ${ }^{+} \mathrm{F} 4 / 80^{-}$dendritic cells (DCs) was significantly higher in both genotypes fed an HFD compared with chow-fed mice. CD11 $\mathrm{c}^{+} \mathrm{DCs}$ were significantly lower in the livers of ST2 ${ }^{-1}$ mice fed either chow or an HFD compared with diet-matched WT mice (Fig. 4A).

HFD feeding significantly increased the percentage of CD11b ${ }^{+}$Ly6C ${ }^{\text {low }}$ cells in WT mice compared with HFD-fed $\mathrm{ST}^{--}$mice. In contrast, HFD increased the percentages of CD11b ${ }^{+}$Ly $6 C^{\text {high }}$ cells in both genotypes, and the proportion of these cells was significantly higher in both chowand HFD-fed ST2 ${ }^{--}$mice compared with diet-matched WT mice (Fig. 4B). 
Figure 4. Phenotypic analysis of immune cells in the liver

A. The percentage of $\mathrm{F} 4 / 80^{+}$macrophages was significantly higher in WT mice fed an HFD compared with WT mice fed a chow diet. The percentage of $\mathrm{CD} 11 \mathrm{c}^{+} \mathrm{F} 4 / 80^{-}$cells was significantly higher in groups fed an HFD compared with the chow-fed groups. The percentage of $\mathrm{CD} 11 \mathrm{c}+\mathrm{F} 4 / 80^{-}$cells was significantly lower in $\mathrm{ST}_{2}^{--}$mice fed a chow diet compared with WT mice fed chow and was also significantly lower in $\mathrm{ST}^{-/-}$mice fed an HFD compared with WT mice fed an HFD.

B. The percentage of $C D 11 b^{+} L y 6 C^{\text {low }}$ cells was significantly higher in WT mice fed an HFD compared with WT mice fed chow as well as with $\mathrm{ST}_{2}{ }^{--}$mice fed an HFD. The percentage of $\mathrm{CD} 11 \mathrm{~b}^{+}$Ly6 $\mathrm{C}^{\text {high }}$ cells was significantly higher in both the chow- and HFD-fed ST2 ${ }^{-/}$mice compared with dietmatched WT mice.

C. Among the gated CD4+ cells, no difference in the percentages of IFN- $\gamma$ producing cells was found. The percentage of IL-17-producing CD4+ cells was significantly lower in $\mathrm{ST}_{2} \%$ mice fed an HFD compared with WT mice fed an HFD.
$A_{14}$
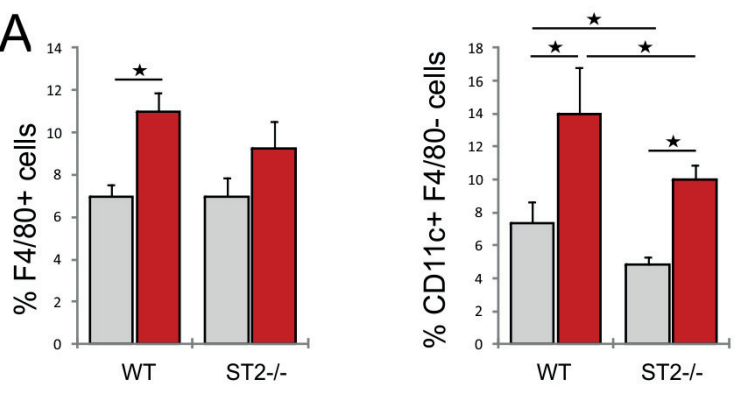

B
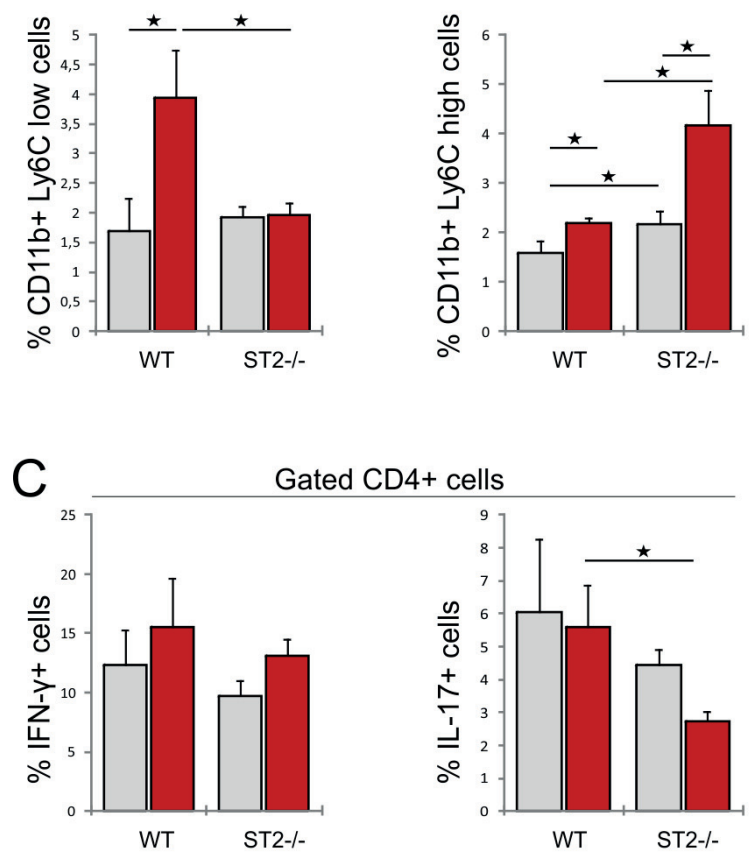

Among gated $\mathrm{CD}_{4}^{+} \mathrm{T}$ cells, no difference in the percentage of IFN- $\gamma$ producing cells was observed among the genotypes of mice fed either chow or an HFD. However, the percentage of IL-17-producing $\mathrm{CD}^{+} \mathrm{T}$ cells was significantly lower in HFD-fed ST2 ${ }^{--}$mice compared with HFD-fed WT mice (Fig. 4C).

The expression of genes related to liver lipid metabolism and fibrosis and cytokine profiles in the sera of WT and ST2 ${ }^{-/-}$BALB/c mice

HFD significantly increased the expression of ATP binding cassette sub-family A member 1 (Abca-1), CD36 and oxysterol receptor LXR-alpha (LXR- $\alpha$ ) genes in the livers of WT mice compared with chow-fed animals; no differences were observed in the mRNA levels of peroxisome proliferator-activated receptor gamma (PPAR- $\gamma$ ) (Fig. 5A). LXR $\alpha$ and PPAR- $\gamma$ expression was significantly lower in HFD-fed ST2 ${ }^{-/}$mice compared with diet-matched WT mice.

HFD significantly increased expression of the liver fibrosis-related genes collagen alpha 1 chain precursor (procollagen), and alpha smooth muscle actin ( $\alpha \mathrm{SMA}$ ) and the profibrotic genes IL-33 and IL-13 in the livers of WT mice compared with chow-fed animals (Fig 5B). In ST2 ${ }^{-1}$ mice, HFD feeding led to significantly increased $\alpha$ SMA expression. The expression of procollagen, IL-33 and IL-13 was significantly lower in ST2 $2^{--}$vs. WT mice, both fed an HFD. TGF- $\beta$ precursor expression was not influenced by HFD feeding in both genotypes, although its expression was significantly higher in chow-fed ST2 ${ }^{-/}$mice compared with diet-matched WT mice (Fig. 5B).

We also analysed serum proinflammatory and profibrotic cytokine levels in WT and ST2 ${ }^{-1}$ mice fed to an HFD for 24 weeks, as indicated in Figure 5. The levels of TNF- $\alpha$, IL-13 and IL-33 were significantly lower in the sera of ST2 $2^{-/}$mice compared with WT mice (Fig. 5C).

\section{DISCUSSION}

Mice on a BALB/c background are relatively resistant to HFD-induced obesity (23). However, we demonstrate that HFD-fed ST2-deficient mice had significantly higher body weight gain compared with wild type mice. It appears that ST2 deletion may partially attenuate the resistance to diet-induced obesity. This result is in accordance with previous studies, which suggested that 


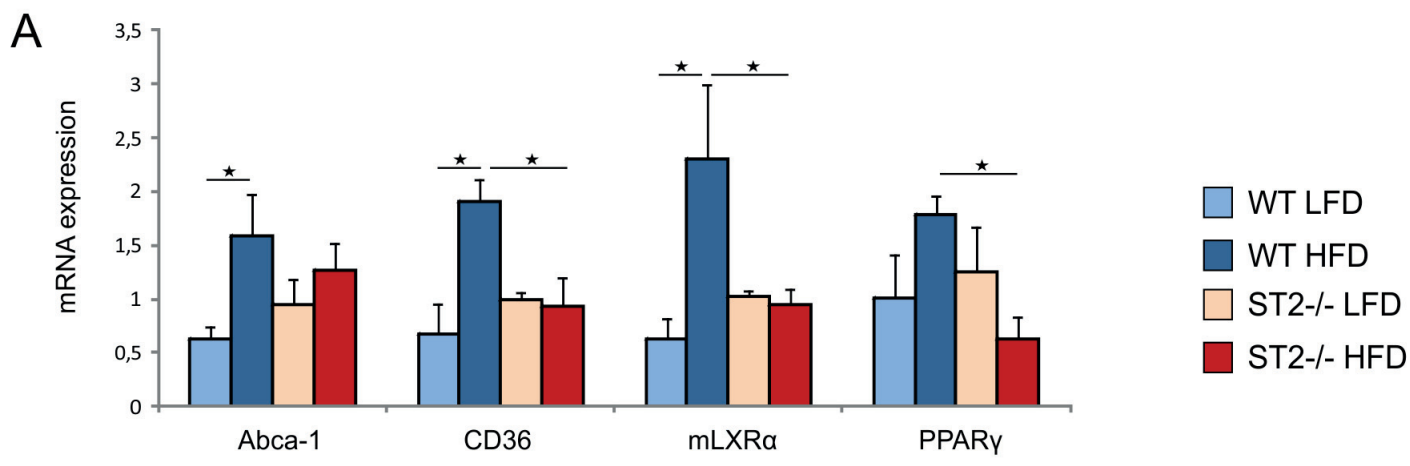

B
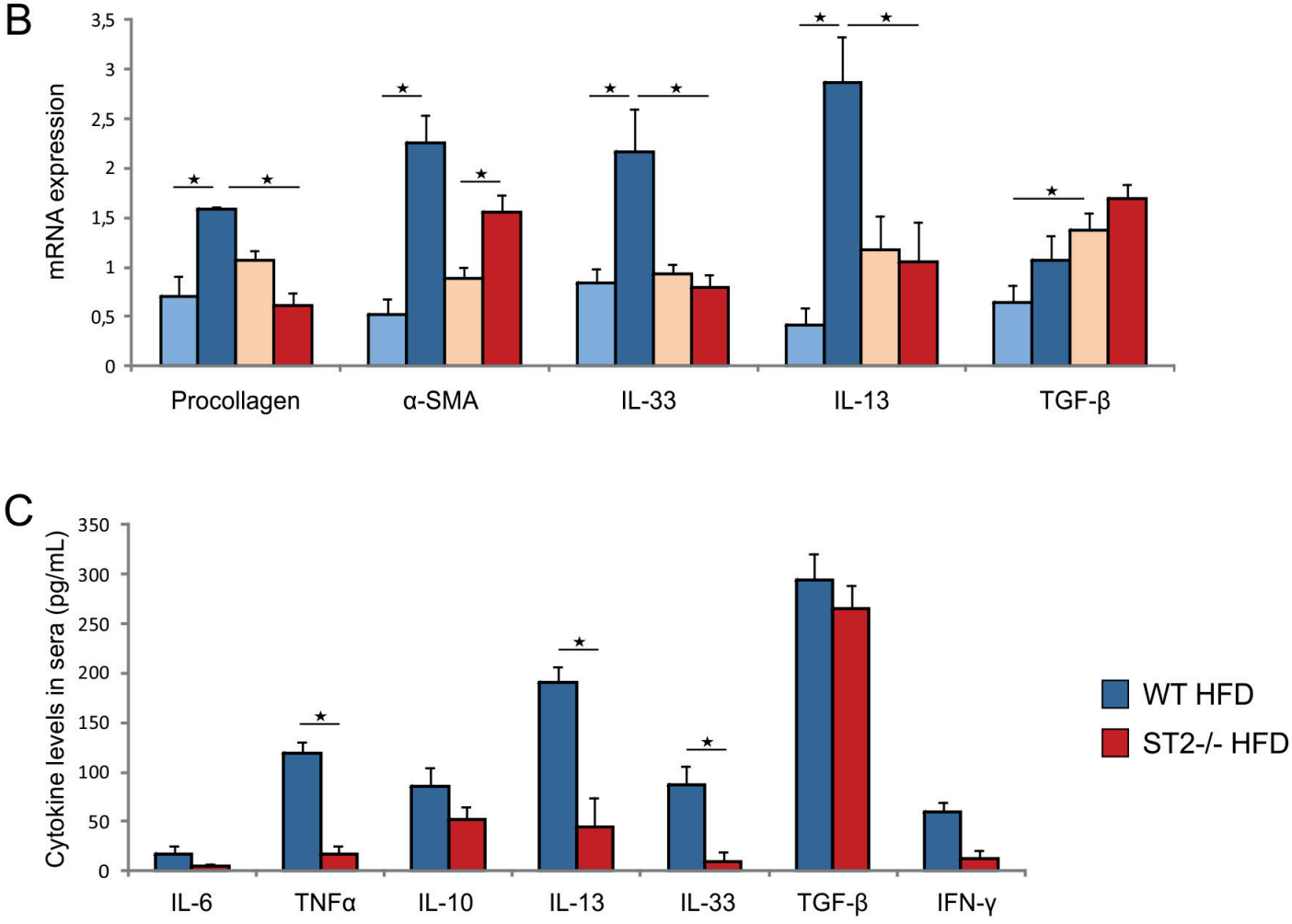

Figure 5. Liver gene expression and cytokine profiles in sera

A. There were no significant differences in the expression of genes related to lipid metabolism in the livers of ST2 ${ }^{--}$mice fed chow and an HFD. Significantly increased expression of the Abca-1, CD36 and LXR- $\alpha$ genes was observed in W T mice fed an HFD compared with WT mice fed a chow diet. The expression of CD36, LXRa and PPAR- $\gamma$ was significantly lower in ST2 ${ }^{-/}$mice fed an HFD compared with diet-matched WT mice.

B. Expression of the procollagen, alpha smooth muscle actin, IL-33 and IL-13 genes was significantly increased in the livers of WT mice fed an HFD compared with WT mice fed chow. The expression of $\alpha$ SMA was significantly higher in the livers of ST2 ${ }^{-/}$mice fed an HFD compared with ST2 ${ }^{-}$ mice fed chow. The expression of IL-33 and IL-13 was significantly lower in ST2 ${ }^{-/}$mice fed an HFD compared with WT mice fed an HFD. Expression of the TGF- $\beta$ precursor was significantly higher in ST2 ${ }^{-/-}$mice fed chow compared with diet-matched WT mice.

C. The levels of TNF- $\alpha$, IL-13 and IL-33 were significantly lower in the sera of ST2 $2^{-/-}$mice fed an HFD compared with diet-matched WT mice.

IL-33 plays a protective role in obesity (12). Miller et al. have previously demonstrated that exogenous IL-33 exerted protective effects on adiposity and inflammation, and Pantic et al. showed that ST2 deletion enhanced visceral adiposity and inflammation in BALB/c mice. In line with these studies $(12,24)$ we also demonstrate the higher amount of visceral adipose tissue in $\mathrm{ST}^{-1-}$ mice maintained on an HFD. Our main objective in this study was to investigate the unresolved role of the IL-33/ST2 axis in the development of hepatic steatosis. We demonstrate here that HFD-induced steatosis was ameliorated in $\mathrm{ST}_{2}^{-1-}$ mice compared with wild-type mice. Furthermore, the extent of liver steatosis was also significantly lower in $\mathrm{ST}_{2}^{-1-}$ mice on a standard diet compared with diet-matched WT mice. The lack of IL-33/ST2 signalling resulted in increased visceral fat weight and hypertriglyceridemia and attenuated liver steatosis in mice fed an HFD. This finding was somewhat unexpected consider- 
ing that enhanced lipolysis in enlarged adipose tissues in obesity was shown to be the main contributing factor in the development of liver steatosis $(9,25)$. Adipose tissue lipolysis is the catabolic process leading to the breakdown of triglycerides stored in fat cells and the release of fatty acids and glycerol (26). Our findings imply that the protective effect of IL-33 in the obesity-associated enlargement of visceral adipose tissue is not exerted on hepatic steatosis. The role of IL-33/ST2 signalling in hepatic steatosis has not been investigated. Recent report suggests that IL-33/ST2 expression may promote maternal lipolysis during pregnancy (27). It could be speculated that the discrepancy between the protective effects on HFD-induced adiposity and enhanced liver steatosis may be related to the presumption that IL-33 promotes lipolysis and the "relocation" of fatty acids in the liver. Furthermore, we demonstrated that WT mice fed an HFD have increased expression of genes associated with lipid metabolism in the liver. The expression of fatty acid translocase (CD36/FAT) was significantly higher in WT mice than in ST2 ${ }^{-/}$mice, both fed an HFD. When fatty acids are released from adipose tissue stores, they enter the circulation as FFAs. CD36 is a molecule involved in the uptake of fatty acids by cells (28). We show markedly lower LXR $\alpha$ expression in HFD-fed $\mathrm{ST}^{-1-}$ mice compared with HFD-fed WT mice. Liver X receptor alpha (LXR $\alpha)$ is oxysterol-activated nuclear receptor that is expressed in the liver and in other tissues and that regulates inflammation and lipogenesis. It has been demonstrated that $L X R \alpha$ activation has potentially deleterious effects by promoting hepatic steatosis and insulin resistance $(29,30)$. As opposed to ST2 ${ }^{-1}$ mice, WT mice fed an HFD had increased expression of peroxisome proliferator-activated receptor (PPAR $\gamma$ ), which has been associated with exacerbated steatosis when overexpressed in hepatocytes (31).

Our findings point to an important role for IL-33/ ST2 signalling in obesity-associated changes in lipid metabolism in the liver. A recent study showed that the development of hepatic steatosis requires IL-1 signalling (10), and considering that the IL-33/ST2 axis shares similar downstream molecules with the IL-1 pathway, IL-33/ST2 signalling should be further explored in hepatic lipogenesis. Recently, the direct role of IL-17 in liver steatosis and fibrosis has been demonstrated $(32,33)$. In accordance with this finding, we showed that IL-17producing $\mathrm{CD} 4^{+}$cells were less numerous in the livers of HFD-fed ST2 ${ }^{-}$mice compared with diet-matched WT mice. Liver inflammation was attenuated in $\mathrm{ST}^{-1-}$ mice fed an HFD, as evaluated by lower inflammatory scores and lower numbers of $\mathrm{CD} 68^{+}$macrophages and percentages of CD11 $\mathrm{c}^{+} \mathrm{DCs}$ in the livers of these mice compared with diet-matched WT mice. Liver damage due to pronounced steatosis in WT mice has been coupled with on-going fibrosis. In contrast to HFD-fed ST2 ${ }^{-\digamma}$ mice, higher gene expression of procollagen, IL-33 and profibrotic IL-13 observed in the livers of HFD-fed WT mice supports the notion of the profibrotic role of IL-33/ ST2 signalling in the liver. This was accompanied by increased collagen deposition in steatotic livers of HFD-fed WT mice and increased sera levels of IL-33 and IL-13. In addition, we also demonstrated that $\mathrm{CD} 11 \mathrm{~b}+\mathrm{Ly} 6 \mathrm{c}^{\text {low }}$ monocytes, which are cells with profibrotic or M2-type functions in the liver $(34,35,36)$, were more numerous in the livers of HFD-fed WT mice compared with dietmatched ST2 ${ }^{-/}$mice.

\section{Conclusion}

In summary, our findings are compatible with the notion that the IL-33/ST2 (IL-33R) axis may play multiple roles in obesity-associated metabolic disorders and NAFLD. IL-33/ST2 signalling attenuates adiposity and inflammation in visceral adipose tissue but promotes liver steatosis, inflammation and fibrosis, most likely by modulating cell trafficking and the metabolic pathways that link adipose and liver tissues in obesity.

\section{Acknowledgments}

We would like to thank Ivan Jovanovic, Gordana Radosavljevic, Jelena Pantic, Aleksandar Ilic, Katerina Martinova, Sandra Nikolic (Center for Molecular Medicine) and Zoran Mitrovic (Institute of Pathology) for their technical assistance.

\section{Grants}

This work was supported by grants from the Serbian Ministry of Science and Technological Development (175071 and 175069) (Belgrade, Serbia), a joint research project (SCOPES, IZ73Z0_152407) and the Internal Projects of Faculty of Medical Sciences (JP 02-14, JP 03-14) (Kragujevac, Serbia).

\section{Disclosure}

The authors declare that they have no competing interests or other interests that might be perceived to influence the results and discussion reported in this paper.

\section{REFERENCES}

1. Cohen JC, Horton JD, Hobbs HH. Human fatty liver disease: old questions and new insights. Science. 2011;332(6037):1519-23.

2. Henao-Mejia J, Elinav E, Jin C, Hao L, Mehal WZ, Strowig $\mathrm{T}$, et al. Inflammasome-mediated dysbiosis regulates progression of NAFLD and obesity. Nature. 2012;482(7384):179-85. 
3. Choi S, Diehl AM. Role of inflammation in nonalcoholic steatohepatitis. Current opinion in gastroenterology. 2005;21(6):702-7.

4. Mouralidarane A, Soeda J, Visconti-Pugmire C, Samuelsson AM, Pombo J, Maragkoudaki X, et al. Maternal obesity programs offspring nonalcoholic fatty liver disease by innate immune dysfunction in mice. Hepatology. 2013;58(1):128-38.

5. Li Z, Soloski MJ, Diehl AM. Dietary factors alter hepatic innate immune system in mice with nonalcoholic fatty liver disease. Hepatology. 2005;42(4):880-5.

6. Grarup N, Sandholt CH, Hansen T, Pedersen O. Genetic susceptibility to type 2 diabetes and obesity: from genome-wide association studies to rare variants and beyond. Diabetologia. 2014;57(8):1528-41.

7. Lin YC, Chang PF, Chang MH, Ni YH. Genetic variants in GCKR and PNPLA3 confer susceptibility to nonalcoholic fatty liver disease in obese individuals. Am J Clin Nutr. 2014;99(4):869-74.

8. Postic C, Girard J. Contribution of de novo fatty acid synthesis to hepatic steatosis and insulin resistance: lessons from genetically engineered mice. J Clin Invest. 2008;118(3):829-38.

9. Ferre P, Foufelle F. Hepatic steatosis: a role for de novo lipogenesis and the transcription factor SREBP-1c. Diabetes, obesity \& metabolism. 2010;12 Suppl 2:83-92.

10. Negrin KA, Roth Flach RJ, DiStefano MT, Matevossian A, Friedline RH, Jung D, et al. IL-1 signaling in obesityinduced hepatic lipogenesis and steatosis. PLoS One. 2014;9(9):e107265.

11. Milovanovic M, Volarevic V, Radosavljevic G, Jovanovic I, Pejnovic N, Arsenijevic N, et al. IL-33/ST2 axis in inflammation and immunopathology. Immunol Res. 2012;52(1-2):89-99.

12. Miller AM, Asquith DL, Hueber AJ, Anderson LA, Holmes WM, McKenzie AN, et al. Interleukin-33 induces protective effects in adipose tissue inflammation during obesity in mice. Circ Res. 2010;107(5):650-8.

13. Marvie P, Lisbonne M, L'Helgoualc'h A, Rauch M, Turlin B, Preisser L, et al. Interleukin-33 overexpression is associated with liver fibrosis in mice and humans. J Cell Mol Med. 2010;14(6b):1726-39.

14. McHedlidze T, Waldner M, Zopf S, Walker J, Rankin $\mathrm{AL}$, Schuchmann M, et al. Interleukin-33-dependent innate lymphoid cells mediate hepatic fibrosis. Immunity. 2013;39(2):357-71.

15. Townsend MJ, Fallon PG, Matthews DJ, Jolin HE, McKenzie AN. T1/ST2-deficient mice demonstrate the importance of T1/ST2 in developing primary T helper cell type 2 responses. J Exp Med. 2000;191(6):1069-76.

16. Junqueira LC, Bignolas G, Brentani RR. Picrosirius staining plus polarization microscopy, a specific method for collagen detection in tissue sections. Histochem J. 1979;11(4):447-55.

17. Hadi AM, Mouchaers KT, Schalij I, Grunberg K, Meijer GA, Vonk-Noordegraaf A, et al. Rapid quantification of myocardial fibrosis: A new macro- based automated analysis. Anal Cell Pathol (Amst). 2010;33(5):257-69.

18. Deutsch MJ, Schriever SC, Roscher AA, Ensenauer R. Digital image analysis approach for lipid droplet size quantitation of Oil Red O-stained cultured cells. Anal Biochem. 2014;445:87-9.

19. Juluri R, Vuppalanchi R, Olson J, Unalp A, Van Natta ML, Cummings OW, et al. Generalizability of the nonalcoholic steatohepatitis Clinical Research Network histologic scoring system for nonalcoholic fatty liver disease. J Clin Gastroenterol. 2011;45(1):55-8.

20. Volarevic V, Mitrovic M, Milovanovic M, Zelen I, Nikolic I, Mitrovic S, et al. Protective role of IL-33/ST2 axis in Con A-induced hepatitis. J Hepatol. 2012;56(1):2633.

21. Foster B, Prussin C, Liu F, Whitmire JK, Whitton JL. Detection of intracellular cytokines by flow cytometry. Curr Protoc Immunol. 2007; Chapter 6:Unit 6.24.

22. Livak KJ, Schmittgen TD. Analysis of relative gene expression data using real-time quantitative PCR and the 2(-Delta Delta $\mathrm{C}(\mathrm{T}))$ Method. Methods. 2001;25(4):402-8.

23. Montgomery MK, Hallahan NL, Brown SH, Liu M, Mitchell TW, Cooney GJ, et al. Mouse strain-dependent variation in obesity and glucose homeostasis in response to high-fat feeding. Diabetologia. 2013;56(5):1129-39.

24. Pantic JM, Pejnovic NN, Radosavljevic GD, Jovanovic I.P, Djukic ALJ, Arsenijevic NN, Lukic ML. Lack of ST2 enhances high - fat diet -induced visceral adiposity and inflammation in BALB/c mice [Delecija gena za ST2 promoviše gojaznost i inflamaciju $u$ visceralnom adipoznom tkivu BALB/c miševa na dijeti sa visokim sadržajem masti]. Serb J Exp Clin Res 2013; 14(4): 155 -160.

25. Donnelly KL, Smith CI, Schwarzenberg SJ, Jessurun J, Boldt MD, Parks EJ. Sources of fatty acids stored in liver and secreted via lipoproteins in patients with nonalcoholic fatty liver disease. J Clin Invest. 2005;115(5):1343-51.

26. Langin D. Adipose tissue lipolysis as a metabolic pathway to define pharmacological strategies against obesity and the metabolic syndrome. Pharmacol Res. 2006;53(6):482-91.

27. McKenna LA, Jordan F, Brown EA, Huda SS, Mackay VA, Miller AM, et al. The role of interleukin-33 and its receptor ST2 in human pregnancy. Archives of Disease in Childhood - Fetal and Neonatal Edition. 2011;96(Suppl 1):Fa98.

28. Su X, Abumrad NA. Cellular fatty acid uptake: a pathway under construction. Trends Endocrinol Metab. 2009;20(2):72-7.

29. Grefhorst A, Parks EJ. Reduced insulin-mediated inhibition of VLDL secretion upon pharmacological activation of the liver $\mathrm{X}$ receptor in mice. J Lipid Res. 2009;50(7):1374-83.

30. Beaven SW, Matveyenko A, Wroblewski K, Chao L, Wilpitz D, Hsu TW, et al. Reciprocal regulation of hepatic and adipose lipogenesis by liver $\mathrm{X}$ receptors 
in obesity and insulin resistance. Cell metabolism. 2013;18(1):106-17.

31. Moran-Salvador E, Lopez-Parra M, Garcia-Alonso V, Titos E, Martinez-Clemente M, Gonzalez-Periz A, et al. Role for PPARgamma in obesity-induced hepatic steatosis as determined by hepatocyte- and macrophage-specific conditional knockouts. FASEB J. 2011;25(8):2538-50.

32. Tang Y, Bian Z, Zhao L, Liu Y, Liang S, Wang Q, et al. Interleukin-17 exacerbates hepatic steatosis and inflammation in non-alcoholic fatty liver disease. Clin Exp Immunol. 2011;166(2):281-90.

33. Tan Z, Qian X, Jiang R, Liu Q, Wang Y, Chen C, et al. IL-17A plays a critical role in the pathogenesis of liver fibrosis through hepatic stellate cell activation. J Immunol. 2013;191(4):1835-44.
34. Lin SL, Castano AP, Nowlin BT, Lupher ML, Jr., Duffield JS. Bone marrow Ly6Chigh monocytes are selectively recruited to injured kidney and differentiate into functionally distinct populations. J Immunol. 2009;183(10):6733-43.

35. Karlmark KR, Weiskirchen R, Zimmermann HW, Gassler N, Ginhoux F, Weber C, et al. Hepatic recruitment of the inflammatory Gr1+ monocyte subset upon liver injury promotes hepatic fibrosis. Hepatology. 2009;50(1):261-74.

36. Tacke F. Functional role of intrahepatic monocyte subsets for the progression of liver inflammation and liver fibrosis in vivo. Fibrogenesis \& tissue repair. 2012;5(Suppl 1 Proceedings of Fibroproliferative disorders: from biochemical analysis to targeted therapiesPetro E Petrides and David Brenner):S27. 